\title{
Use of Herbal Medicines to Induce Labour by Pregnant Women: A Systematic Review of Literature
}

\author{
Catherine Mubita Ngoma* and Brenda Siachapa \\ University of Zambia, Zambia
}

Submission: May 30, 2017; Published: June 27, 2017

*Corresponding author: Catherine Mubita Ngoma, University of Zambia, Zambia, Email: catherinengoma@yahoo.com

Abstract

The use of herbal medicine to induce or accelerate labour is commonly practiced in many cultures world wide, however, this is of great concern in some African countries, Zambia inclusive because of its effects on the health of the mother and foetus. This paper analyses the growing literature relating to use of Herbal medicines to induce labour by pregnant women and commonly used herbs and concludes that more research is required to under this phenomenon. Articles published from 2006 to 2017 were reviewed. The electronic data bases were searched and 10 studies were identified.

Keywords: Herbal medicine; Induce; Labour

\section{Introduction}

The use of herbs to induce labour is still common among some pregnant women in some parts of the country; however, little is known scientifically about the safety of most herbs during pregnancy and labour. This is because the herbs might have harmful effects on both the mother and the foetus. According to Born and Barron some plants contain natural toxins that could be dangerous if consumed. This review examines the empirical literature regarding use of Herbal medicines to induce labour by pregnant women.

The world health organisation defines normal labour as low risk throughout, spontaneous in onset with the foetus presenting by the vertex, culminating in the mother and infant in good condition following birth. The course of normal labour consists of regular progression of uterine contractions, effacement and progressive dilatation of the cervix and progress in descent of the presenting part. There is increasing acknowledgment that there are more than three stages of normal labour. The first stage of labour lasts from the onset of regular uterine contractions to full dilatation of the cervix and is divided into three phases; the latent, active and transition phases. The second stage of labour is that of expulsion of the fetus, it begins when the cervix is fully dilated and it is complete when the baby is born. The third stage of labour lasts from the birth of the baby of the baby until the placenta and membranes have been expelled. According to
Lowdermilk and Perry, the fourth stage of labour is the period of immediate recovery when homeostasis is re-established.

\section{Main Objective of the Review}

To determine the prevalence and common herbal medicines used to induce labourby pregnant women.

\section{Literature review}

A search of the literature assessing the use of Herbal medicines to induce labour by pregnant women was undertaken using electronic data bases such as Medline, Pub med, Science direct using keywords "Normal labour and Use of herbs to induce labour".Medical subjects handling terms (MeSH) and free terms such as herbs used to induce labour, herbal use during pregnancy and traditional herbs were used for the search.

The search was limited to English full-length research articles in peer reviewed journals from the year 2002 to 2017 inclusive. All research articles that describe the use of herbal medicines during labour by pregnant women were included.

\section{Results}

A total of 55 articles were identified and reviewed for suitability. Of those articles, 11 met the inclusion criteria.The articles were reviewed for Author/s and year of publication, study tittle, setting, design, sample size, prevalence of herbal 
use and name of herbs used. Among the studies reviewed, 9 are from African countries namely Zambia, Tanzania, South Africa, Nigeria, Zimbabwe and two from Ghana. The other two studies

are from Omani and Malaysia. The study designs ranged from quantitative, qualitative and systematic review. The summary of the studies is indicated in Table 1 below.

Table 1: Studies on use of herbs during labour.

\begin{tabular}{|c|c|c|c|c|c|c|}
\hline $\begin{array}{c}\text { Author/S and Year } \\
\text { of Publication }\end{array}$ & Study Title & $\begin{array}{l}\text { Study } \\
\text { Setting }\end{array}$ & $\begin{array}{l}\text { Study } \\
\text { Design }\end{array}$ & Sample & $\begin{array}{c}\text { Prevalence } \\
\text { of Herbal } \\
\text { Use }\end{array}$ & Name of Herbs Used \\
\hline Maluma S et al. [1] & $\begin{array}{c}\text { Prevalence of } \\
\text { traditional herbal } \\
\text { medicine use and } \\
\text { associated factors } \\
\text { among pregnant } \\
\text { women of Lusaka } \\
\text { Province }\end{array}$ & Zambia & $\begin{array}{c}\text { Cross } \\
\text { sectional study }\end{array}$ & $\begin{array}{c}273 \text { pregnant } \\
\text { women }\end{array}$ & $32 \%$ & $\begin{array}{c}\text { Traditional herbs Moono, } \\
\text { Mulolo }\end{array}$ \\
\hline Dika et al. [2] & $\begin{array}{l}\text { Prevalent use } \\
\text { of herbs for } \\
\text { reduction of } \\
\text { labour duration } \\
\text { in Mwanza, } \\
\text { Tanzania: Are } \\
\text { obstetricians } \\
\text { aware? }\end{array}$ & Tanzania & $\begin{array}{c}\text { Cross sectional } \\
\text { study }\end{array}$ & $\begin{array}{l}178 \text { study } \\
\text { participants }\end{array}$ & $23 \%$ & $\begin{array}{l}\text { Ginger (Zingier officinale), } \\
\text { Onions (Allium cepa) } \\
\text { Neem } \\
\text { (Azadirachtaindica). }\end{array}$ \\
\hline Adusi-pokuIo Y et al. [3] & $\begin{array}{l}\text { Type of Herbal } \\
\text { medicines utilized } \\
\text { by pregnant } \\
\text { women attending } \\
\text { antenatal clinic } \\
\text { in Offinso } \\
\text { North District: } \\
\text { Are orthodox } \\
\text { prescribers } \\
\text { aware? }\end{array}$ & Ghana & $\begin{array}{l}\text { Cross sectional } \\
\text { study }\end{array}$ & $\begin{array}{l}384 \text { pregnant } \\
\text { women }\end{array}$ & $6.5 \%$ & $\begin{array}{c}\text { Cassia occidentalis } \\
\text { Sidaacuta, Cola giganteaA } \\
\text { nnonasenegalensis, } \\
\text { Nauclealatifolia }\end{array}$ \\
\hline $\begin{array}{c}\text { Ramasubramaniam S } \\
\text { et al. [4] }\end{array}$ & $\begin{array}{c}\text { Use of herbal } \\
\text { preparations } \\
\text { among parturient } \\
\text { women: Is there } \\
\text { enough evidence- } \\
\text { A literature } \\
\text { review }\end{array}$ & Oman & $\begin{array}{l}\text { Systematic } \\
\text { review }\end{array}$ & 9 articles & - & $\begin{array}{c}\text { Blue and Black cohosh, } \\
\text { Isihlambezo, raspberry } \\
\text { leaves, castor oil raspberry } \\
\text { leaves, evening primrose oil, } \\
\text { Rasberyleaf,Ginger, } \\
\text { Echinacrea, canbery, leaves, } \\
\text { Flora } \\
\text { dix ginseng, Valerian and } \\
\text { chanlibao }\end{array}$ \\
\hline Maputle MS et al.[5] & $\begin{array}{c}\text { Traditional } \\
\text { medicine and } \\
\text { pregnancy } \\
\text { management : } \\
\text { Perceptions of } \\
\text { traditional health } \\
\text { practitioners in } \\
\text { Capricorn district, } \\
\text { Limpopo province }\end{array}$ & South Africa & Qualitative & $\begin{array}{l}8 \text { Traditional } \\
\text { Health } \\
\text { Practitioners }\end{array}$ & - & Agapanthus and typhasp \\
\hline Otoo P et al. [6] & $\begin{array}{c}\text { Food prohibitions } \\
\text { and other } \\
\text { traditional } \\
\text { practices in } \\
\text { pregnancy: A } \\
\text { qualitative study } \\
\text { in Western region } \\
\text { of Ghana }\end{array}$ & Ghana & Qualitative & $\begin{array}{l}8 \text { to } 10 \\
\text { participants } \\
\text { in } 6 \text { focus } \\
\text { groups } \\
\text { discussions } 8 \\
\text { informants }\end{array}$ & & $\begin{array}{l}\text { Setedua, trontrofo, } \\
\text { akokonyidemeguwekyir } \\
\text { and eban, } \\
\text { awombreduro,aponsoe, } \\
\text { nunum } \\
\text { (middle of palm fronts), } \\
\text { the back of cola nut tree }\end{array}$ \\
\hline
\end{tabular}




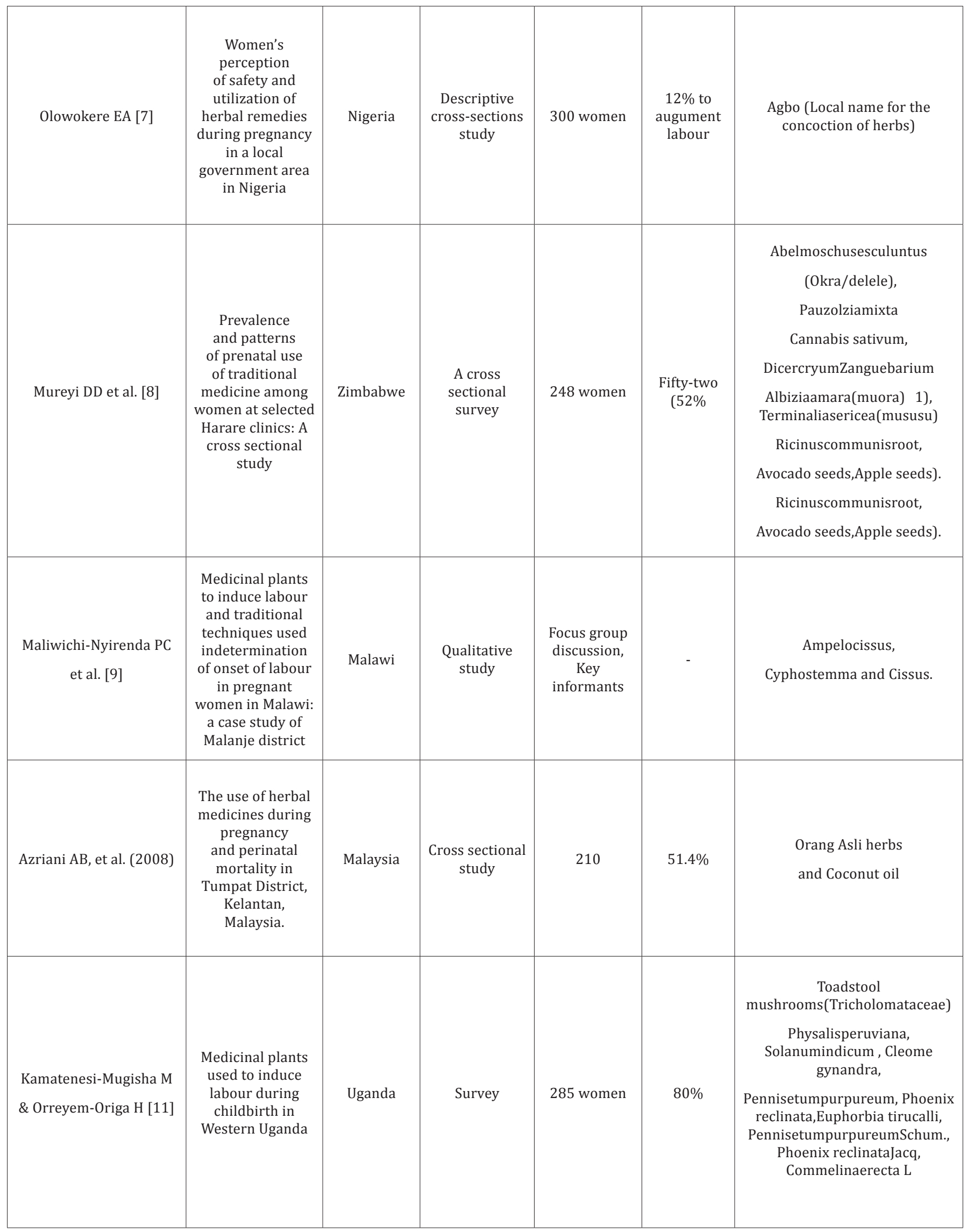




\section{Discussion}

This review of literature suggests that some pregnant women use herbs to induce labour. Previous studies of traditional medicine use have conservatively reported rates between $6.5 \%$ to $80 \%$ in Ghana, Nigeria, Tanzania, Zambia, Malaysia, Zimbabwe and Uganda. A Zambian study by Maluma et al. [1] mentioned Moono and Mulolo (Traditional herbs) as herbs commonly used to induce labour. Ginger (Zingier officinale), Onions (Allium cepa) (Neem (Azadirachtaindica) were identified as herbs used to induce labour by Dika et al. [2], in a cross sectional study conducted in Manza, Tanzania.

Adusi-Pokulo et al. [3] conducted a study in Ghana on Type of Herbal medicines utilized by 384 pregnant women attending antenatal clinic in Offinso North District. The findings revealed that Cassia occidentalis Sidaacuta, Cola gigantean Annona senegalensis, Nauclea latifolia were the common herbs used to induce labour.

A systematic review of literature by Ramasubramaniam et al. [4] in Oman showed that Blue and Black cohosh, Isihlambezo, raspberry leaves, castor oil raspberry leaves, evening primrose oil, Raspberry leaf, Ginger, Echinacrea, canberry leaves, Floradix ginseng, Valerian and chanli bao, are used to induce labour by pregnant women. In a study by Maputle et al. [5] it was reported that Agapanthus and typhasp are also used to induce labour).

Other herbs used to induce labour include Setedua, Trontrofo, akokonyi demeguwekyir and eban, awombreduro, aponsoe, nunum (middle of palm fronts), the back of cola nut tree [6] and Agbo (Local name for the concoction of herbs) [7]. Evidence show that Abelmoschusesculuntus (Okra/delele), Pauzolziamixta, Cannabis sativum, Dicer cryum Zangue barium Albizia amara (muora), Terminalia sericea (mususu), Ricinus communis root, Avocado seeds, Apple seeds) are used to induce labour [8].

In a qualitative study entitled "Medicinal plants to induce labour and traditional techniques used indetermination of onset of labour in pregnant women in Malawi: a case study of Malanje district" by Maliwichi-Nyirenda \& Maliwachi [9] it was revealed that Ampelocissus, Cyphostemma and Cissus are medicinal plants used to induce labour by pregnant women. A study by Rahman et al. [10] in Malaysia showed that Orang Asliherbs and Coconut oil were used to induce labour. Toadstool mushrooms (Tricholomataceae), Physalis peruviana, Solanum indicum, Cleome gynandra, Pennisetum purpureum, Phoenix reclinata, Euphorbia tirucalli, Pennisetum purpureum Schum, Phoenix reclinata Jacq, Commelin aerecta $L$. were also used to induce labour [11].

Herbs used to induce child birth are usually taken towards the end of gestation period or at the on-set of labour pains [11]. Plants that produce uterine contractions have similar action as that of oxytocin hormone, produced on the posterior lobule of the hypophysis, which stimulates the uterus, experience strong contractions, thus producing labour. However, very little is known about the pharmacology and potential toxicity of the plants used in these herbal remedies $[12,13]$.

\section{Conclusion}

The findings of this literature review demonstrate that the traditional herbs are used to induce labour by some women. Evidence from this review suggests that pregnant women use different herbs to induce labour. Therefore there is need to investigate the implications of herbal use to induce labour on pregnancy outcome in order to help women make informed choices.

\section{Limitations of the Study}

Few studies have been conducted on the topic. However, despite these limitations, valuable information was gathered in this investigation and will help direct future studies.

\section{References}

1. Maluma S, Aubrey CK, Audrey H, Jimmy H, Derick M (2017) Prevalence of traditional herbal medicine use and associated factors among pregnant women of Lusaka Province, Zambia.

2. Dika H, Dismas M, Iddi S, Rumanyika R (2017) Prevalent use of herbs for reduction of labour duration in Mwanza, Tanzania: Are obstetricians aware? Tanzania Journal of Health Research 19(2).

3. Adusi-poku Y, Vanotoo L, Detoh EK, Oduro J, Nsiah R, et al. (2015) Type of herbal medicines utilized by pregnant women attending ante-natal clinic in Offinso North district: are orthodox prescribers aware? Ghana Medical Journal 49(4).

4. Ramasubramaniam S, Renganathan L, Vijayalakshmi G, Mallo-Banatao M (2015) Use of herbal preparations among parturient women: Is there enough evidence- A literature review. International Journal of Herbal medicine 2(5): 20-26.

5. Maputle MS, Mothiba MT, Maliwichi L (2015) Traditional medicine and pregnancy management: Perceptions of traditional health practitioners in Capricorn district, Limpopo province, South Africa.

6. Otoo P, Habib H, Ankomah (2015) Food prohibitions and other traditional practices in pregnancy: A qualitative study in Western region of Ghana. Advances in Reproductive Health Sciences 3(3): 4149.

7. Olowokere EA, Olajide $O$ (2013) Women's perception of safety and utilization of herbal remedies during pregnancy in a local government area in Nigeria. Clinical Nursing Studies 1(4).

8. Mureyi DD, Monera TG, Maponga CC (2012) Prevalence and patterns of prenatal use of traditional medicine among women at selected Harare clinics: A cross sectional study. BMC Complement Altern Med 12: 164.

9. Maliwichi-Nyirenda PC, Maliwichi LL (2010) Medicinal plants used to induce labour and traditional techniques used in determination of onset of labour in pregnant women in Malawi: A case study of Mulanje District. Journal of Medicinal Plants Research 4(24): 2609-2614.

10. Rahman AA, Sulaiman SA, Ahmad Z, Daud WN, Hamid AM (2008) Prevalence and Pattern of Use of Herbal Medicines During Pregnancy in Tumpat District, Kelantan. Malays J Med Sci 15(3): 40-48.

11. Kamatenesi-Mugisha M, Oryem-Origa H (2006) Medicinal plants used to induce labour during childbirth in western Uganda. J Ethnopharmacol 109(1): 1-9. 
12. Rahman A, Ahmad Z, Naing L, Sulaiman SA, Hamid AM, et al. (2007) The use of herbal medicines during pregnancy and perinatal mortality in Tumpat District, Kelantan, Malaysia. Southeast Asian J Trop Med Public Health 38(6): 1150-1157.
13. Varga CA, Veale DJ (1997) Isihlambezo: utilization patterns and potential health effects of pregnancy-related traditional herbal medicine. Soc Sci Med 44(7): 911-924.

Your next submission with Juniper Publishers will reach you the below assets

- Quality Editorial service

- Swift Peer Review

- Reprints availability

- E-prints Service

- Manuscript Podcast for convenient understanding

- Global attainment for your research

- Manuscript accessibility in different formats

( Pdf, E-pub, Full Text, Audio)

- Unceasing customer service

Track the below URL for one-step submission https://juniperpublishers.com/online-submission.php 